\title{
Prototype Sistem Parkir Bergerak Berbasis IoT Menggunakan Respberry Pi
}

\author{
Sofia Ariyani, Herry Setyawan, Denny Aptagus Dimas Prasetyo \\ Teknik Elektro, Fakultas Teknik, Universitas Muhammadiyah Jember \\ Jl. Karimata No.49 Jember 68121 Indonesia \\ E-mail: deny.ambulu@gmail.com
}

\begin{abstract}
ABSTRAK
Abstrak - Permasalahan ini sering dijumpai ketika kita berkunjung disuatu tempat khusus seperti, mall, apartemen atau kantor-kantor. Kebanyakan tempat parkir pada hari libur menumpuk dan tidak tertata rapi karena tidak dilengkapi akses informasi slot tempat parkir. Melihat permasalahan tersebut, maka tugas akhir ini membahas tentang mengembangkan teknologi akses tempat parkir berbasis mobile apps android yang bertujuan untuk memberikan solusi teknologi tempat parkir yang berupa rancang bangun prototype sistem parkir bergerak berbasis IoT menggunakan respberry pi. Sistem parkir ini mempermudah pengguna parkir untuk mengetahui akses informasi lokasi yang akan dijadikan tempat parkir. Dari sisi keamanan tempat parkir telah di lengkapi dengan pengaman yang hanya dapat dibuka dengan mobile apps android. Prototype menggunakan sensor infra merah yang digunakan untuk mengetahui kondisi slot keadaan kosong atau terisi oleh mobil, motor servo digunakan sebagai membuka dan menutup palang pintu, mikrokontroller arduino mega 2560 disini adalah sebagai pusat panel yang menerima kondisi hasil pembacaan sensor dari beberapa slot tempat parkir, raspberry pi sebagai pengolah informasi yang kemudian ditampilkan terhadap apps android, IoT (Internet of Things) di gunakan untuk raspberry pi mentransfer data ke apps android begitu juga sebaliknya. Selain prototype juga dihasilkan aplikasi android yang dimana digunakan untuk mendukung kerja prototype tersebut. Pada aplikasi android ini terdapat fitur-fitur seperti menu home, menu riwayat, menu parkir, menu akun, dan menu untuk login. Dengan cara pengujian integrasi antara mobile apps android dengan prototype tempat parkir di dapatkan waktu rata rata akses pintu masuk membutuhkan waktu 1.58 menit dan waktu rata rata akses pintu keluar memerlukan waktu 2.48 menit. Rata rata waktu respon pengguna kolom parkir memerlukan waktu 2.52 menit.
\end{abstract}

Kata kunci: Sistem Parkir, Slot Tempat Parkir, Raspberry Pi, Prototype, Apps Android

ABSTRACT

\begin{abstract}
This problem is often encountered when we visit a special place such as a mall, apartment, or offices. Most of the parking lots on holidays are piled up and not neatly arranged because they are not equipped with access to parking slot information. Seeing these problems, this final project discusses developing parking access technology based on android mobile apps which aims to provide parking space technology solutions in the form of prototyping designs for IoT-based mobile parking systems using raspberry pi. This parking system makes it easier for parking users to find out access to location information that will be used as a parking space. In terms of security, the parking lot has been equipped with security that can only be opened with the Android mobile app. The prototype uses an infrared sensor which is used to determine the condition of the empty or filled slot by a car, the servo motor is used to open and close the door latch, the Arduino Mega 2560 microcontroller here is the center panel that accepts the condition of the sensor readings from several parking slots, raspberry pi as information processing which is then displayed on android apps, IoT (Internet of Things) is used for raspberry pi transferring data to android apps and vice versa. In addition to the prototype, an android application is also produced which is used to support the prototype work. In this Android application, there are features such as the home menu, history menu, parking menu, account menu, and login menu. By testing the integration between the android mobile apps with the parking lot prototype, it is found that the average time for entrance access takes 1.58 minutes and the average time for exit accesses takes 2.48 minutes. The average response time for parking column users takes 2.52 minutes.
\end{abstract}

Keywords: Parking System, Parking Slots, Raspberry Pi, Prototype, Android Application

Copyright (C) 2019 Universitas Muhammadiyah Jember. 


\section{PENDAHULUAN}

Permasalahan ini sering dijumpai ketika kita berkunjung disuatu tempat khusus seperti, mall, apartemen atau kantor-kantor. Pada hari liburan tempat parkir menumpuk tidak tertata rapi karena tidak dilengkapi akses informasi slot tempat parkir. Pengembangan teknologi akses informasi tempat parkir merupakan kebutuhan pada sistem parkir secara otomatis. Akses sistem informasi yang otomatis dapat menjadi media prasarana yang mempermudah pengelolaan parkir dengan rapi. Adapun teknologi yang digunakan adalah sistem otomatis akses informasi mulai dari lokasi (lantai dan blok) hingga jumlah keseluruhan temapat parkir yang kosong maupun terisi. Sehingga pelayanan parkir menjadi sangat informatif dan real time dalam menampilkan slot-slot parkir yang berada di lantai dan blok yang masih tersedia.

Dari permasalahan tempat parkir maka penelitian ini akan mengembangkan teknologi akses informasi tempat parkir berbasis mobile apps android yang bertujuan untuk memberikan solusi teknologi tempat parkir yang berupa rancang bangun prototype dengan judul "Prototype Sistem Parkir Bergerak Berbasis IoT Menggunakan Respberry Pi”. Dalam pemanfaatan mobile apps android mempermudah pengguna parkir untuk mengetahui akses informasi lokasi yang akan dijadikan tempat parkir. Dari sisi keamanan tempat parkir telah di lengkapi dengan pengaman yang hanya dapa dibuka dengan mobile apps android. Beberapa fitur yang ada pada mobile apps android adalah total jumlah, titik lokasi parkir (lantai, blok, dan nomor parkir), pembayaran.

\section{KAJIAN PUSTAKA}

\subsection{Parkir}

Parkir dalam Kamus Besar Bahasa Indonesia adalah keadaan tidak bergerak suatu kendaraan yang bersifat sementara karena ditinggalkan oleh pengemudinya. Sehingga area parkir adalah area khusus yang telah di sediakan untuk kepentingan parkir kendaraan [1].

\subsection{Arduino Mega 2560}

Arduino Mega 2560 adalah board Arduino yang merupakan perbaikan dari board Arduino Mega sebelumnya. Arduino Mega awalnya memakai chip ATmega 1280 dan kemudian diganti dengan chip ATmega 2560, oleh karena itu namanya diganti menjadi Arduino Mega 2560.Arduino Mega 2560 mempunyai 4 port serial, lebih banyak dari Arduino Uno yang hanya punya 1 port serial. Flash Memory sebesar 256KB yang ada di Arduino Mega 2560 rasanya sudah cukup besar untuk kebanyakan program di microcontroller.

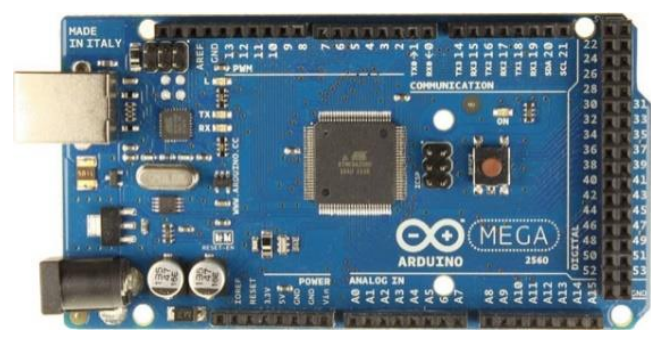

\subsection{Komunikasi Serial}

Gambar 1. Arduino mega 2560 [2]

Komunikasi serial adalah komunikasi yang pengiriman datanya per-bit secara berurutan dan bergantian. Komunikasi ini mempunyai suatu kelebihan yaitu hanya membutuhkan satu jalur dan kabel yang sedikit dibandingkan dengan komunikasi paralel [3].

\subsection{Raspberry Pi}

Raspberry Pi adalah modul micro computer yang juga mempunyai input output digital port seperti pada board microcontroller. Dibandingkan dengan board microcontroller lain, Raspberry Pi mempunyai beberapa kelebihan yaitu mempunyai Port/koneksi untuk display berupa TV atau Monitor PC serta koneksi USB untuk Keyboard dan Mouse. Raspberry Pi dibuat di inggris oleh Raspberry Pi Foundation. Pada awalnya Raspberry Pi ditunjukan untuk modul pembelajaran ilmu komputer di sekolah. 


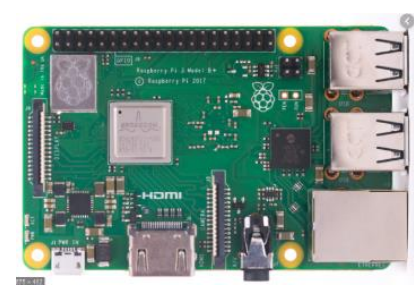

Gambar 2. Raspberry pi [4]

\subsection{Sensor Inframerah (IR)}

Infra red (IR) detektor atau sensor infra merah yaitu komponen elektronika yang dapat mengidentifikasi cahaya infra merah (infra red, IR). Sistem sensor infra merah tersebut pada dasarnya menggunakan infra merah sebagai media untuk komunikasi data antara receiver dan transmitter. Sistem akan bekerja jika sinar infra merah yang dipancarkan terhalang oleh suatu benda yang mengakibatkan sinar infra merah tersebut tidak dapat terdeteksi oleh penerima [5].

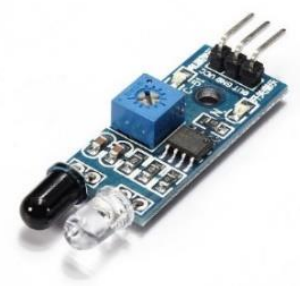

Gambar 3. Module sensor inframerah

\subsection{Android}

Android merupakan sistem operasi untuk telepon seluler atau telepon cerdas (smart phone) dan komputer tablet yang dimana sistem android ini berbasis linux. Pada penelitian ini antarmuka yang dibuat untuk kontroll dari smart home adalah aplikasi (perangkat lunak) Android Mobile Apps. Untuk membuat aplikasi antarmuka pengguna Android Mobile Apps di perlukan aplikasi IDE Android Studio [6].

\subsection{Motor Servo}

Motor servo adalah sebuah motor DC dengan sistem tertutup, di mana posisi rotor-nya akan diinformasikan kembali ke rangkaian kontrol yang ada di dalam motor servo. Motor ini terdiri dari sebuah motor DC, serangkaian gear, potensiometer, dan rangkaian kontrol. Potensiometer berfungsi untuk menentukan batas sudut dari putaran servo. Sedangkan sudut dari sumbu motor servo diatur berdasarkan lebar pulsa yang dikirim melalui kaki sinyal dari kabel motor servo.

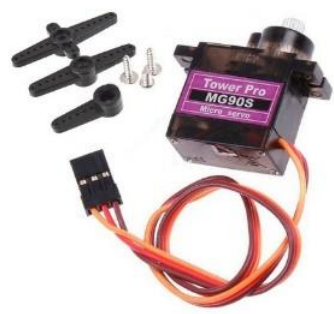

Gambar 4. Motor servo tower pro MG90s

\subsection{LCD (Liquid Crystal Display)}

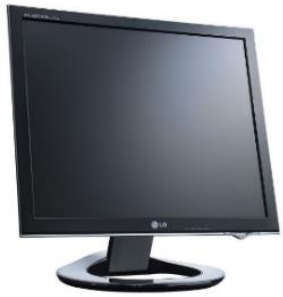

Gambar 5. LCD (Liquid Crystal Display) [7] 
Penampil kristal cair (liquid crystal display) adalah suatu jenis media tampilan yang menggunakan kristal cair sebagai penampil utama. LCD sudah digunakan di berbagai bidang misalnya dalam alatalat elektronik seperti televisi, kalkulator ataupun layar komputer.

\subsection{IoT (Internet of Things)}

IoT adalah singkatan dari Internet of Things. IoT adalah konsep di mana, objek tertentu memiliki kemampuan untuk mentransfer data melalui jaringan. Tanpa memerlukan interaksi dari manusia ke manusia, atau dari manusia ke perangkat komputer. Internet of Things lebih sering disebut dengan singkatannya yaitu IoT. IoT ini juga sering diidentifikasi dengan RFID sebagai metode komunikasi. Meski begitu, IoT juga dapat memasukkan teknologi sensor lain, seperti teknologi nirkabel atau kode QR yang sering kita temukan di sekitar kita [8].

\section{METODE PENELITIAN}

\subsection{Pendahuluan Umum}

Pelaksanaan penelitian untuk membangun sistem otomatis sitem parkir maka akan digunakannya perangkat lunak dan perangkat keras yang mendukung. Dimana perangkat lunak digunakan sebagai metode desain sistem untuk implemetasi dari rumusan masalah. Perangkat keras dalam penelitian digunakan sebagai pendukung menjalankannya perangkat lunak dengan sepesifikasi yang telah sesuai dengan kebutuhan penelitian. Sehingga penelitian dapat membangun prototype sistem parkit otomatis dan informatif sebagai jawaban dari tujuan utama penelitian yang diajukan.

\subsection{Analisa Kebutuhan}

Dari tinjauan pustakan dan studi literasi terkait maka kebutuhan dalam melaksanakan penelitian adalah sebagai berikut:

\subsubsection{Peralatan Penunjang Penelitian}

Penentuan peralatan penunjang dalam melaksanakan penelitian adalah sebagai berikut:

1) 1 buah laptop.

2) 1 set tolkit elektronika (tang, pinset, solder, timah, dll).

\subsubsection{Bahan Penelitian}

Bahan-bahan yang akan di gunakan untuk implementasi dari penelitian yang diajukan yaitu:

1) 1 set raspberry pi.

2) 1 set arduino mega.

3) 1 set power supply.

4) 1 modul lcd raspberry pi.

5) 1 modul komunikasi antarmuka device.

6) 1 set modul prototype area parkir yang teritegrasi dengan sistem elektrik dan sensor.

\subsection{Diagram Blok}

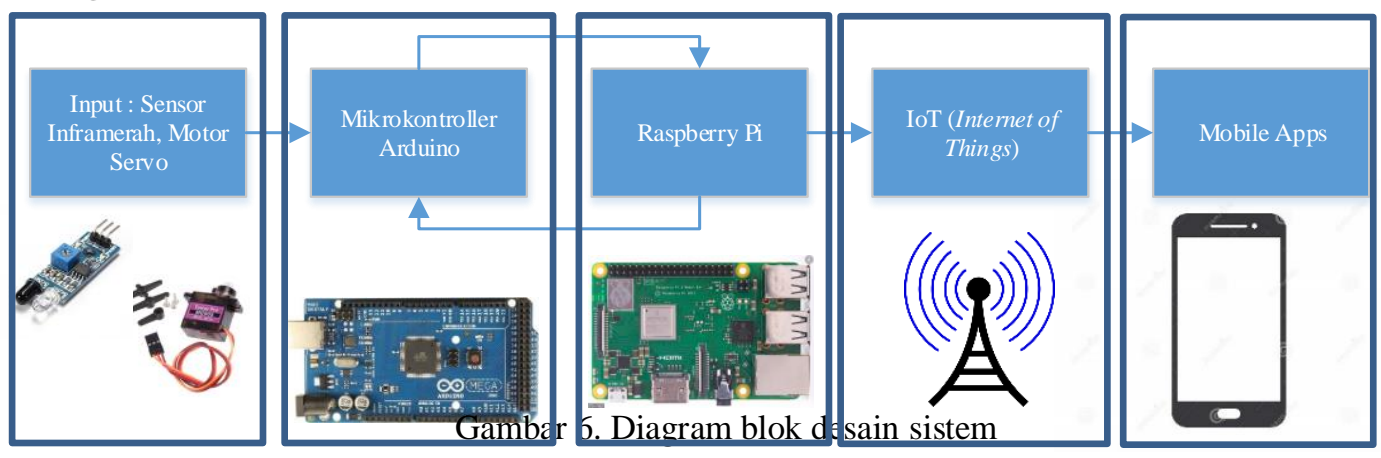

Pada Gambar 6 yaitu diagram blok alur kerja penelitian secara sederhana memberikan skema masing - masing kolom blok. Dan penjelasan alur kerja dari diagram blok adalah:

1) Input

Input yang digunakan dalam penelitian adalah sensor Infrared dan motor servo. Sensor Infrared ini akan terpasang pada sebagian lantai slot parkir sehingga memberikan kondisi slot dalam keadaan kosong atau terisi mobil. Sedangkan untuk motor servonya digunakan untuk membuka dan menutup palang pintunya.

2) Mikrokontroller Arduino 
Mikrokontroller Arduino disini adalah sebagai pusat panel yang menerima kondisi hasil pembacaan sensor dari beberapa slot tempat parkir. Setelah menerima inputan tersebut mikrokonroller arduino akan memproses data tersebut menjadi informasi. Setelah proses data menjadi informasi maka dikirimkan secara serial terhadap raspbery pi. Selain mengirimkan data ke raspberry pi mikrokontroller arduino juga dapat menerima permintaan informasi dari raspberry pi secara real time.

3) Raspberry Pi

Raspberry pi memiliki peranan penting pada penelitian, yaitu sebagai pengolah informasi yang kemudian ditampilkan terhadap modul lcd. Informasi yang diolah dan ditampilkan, diperoleh dengan komunikasi secara serial terhadap mikrokontroller arduino dengan otomatis meminta dan mengirim data informasi.

4) IoT

IoT (Internet of Things) digunakan untuk mentransfer data lewat jaringan tanpa memerlukan adanya interaksi dari manusia ke manusia. Seperti halnya Raspberry pi mentransfer data ke apps android begitu juga sebaliknya.

5) Modul LCD

Modul LCD adalah sebagai penampil dari data informasi yang diproses raspberry pi dalam bentuk antar muka GUI (Graphical User Interface) dengan desain yang memudahkan

\subsection{Flowchart} pengguna area parkir untuk mendapat informasi slot yang kosong pada area parkir.

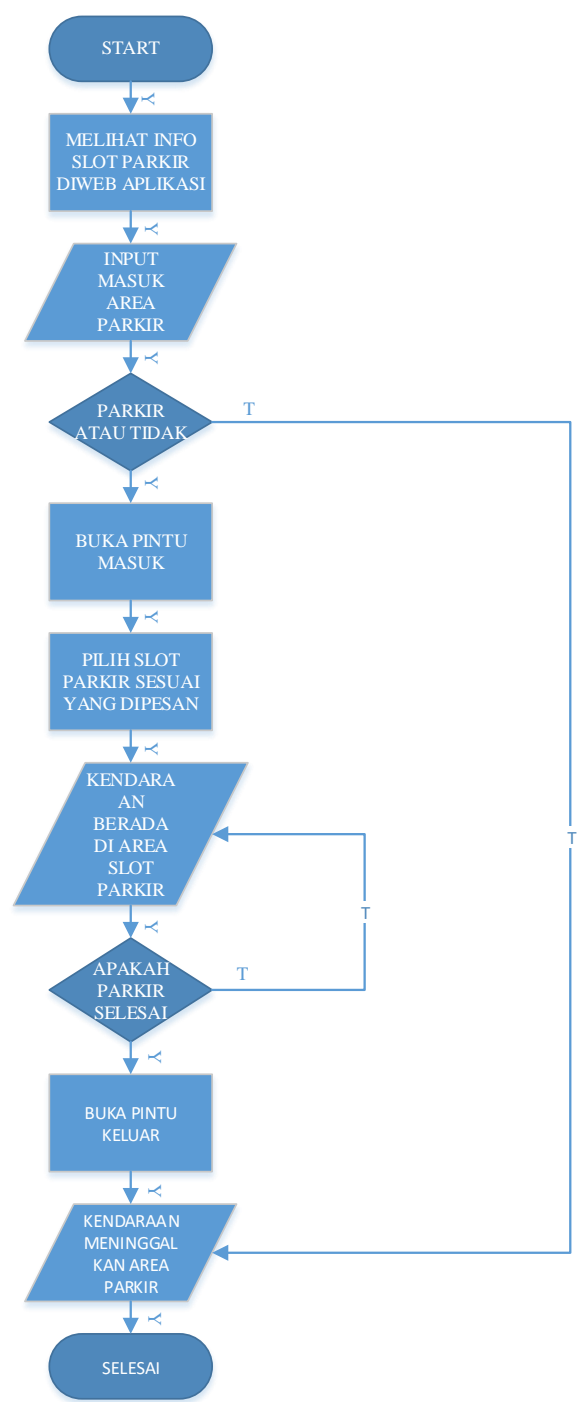

Gambar 7. Flowchart alur kerja sistem penelitian

\subsection{Perencanaan Penelitian}

Beberapa desain dari perencanaan penelitian yang meliputi desain denah parkir sebagai berikut: 


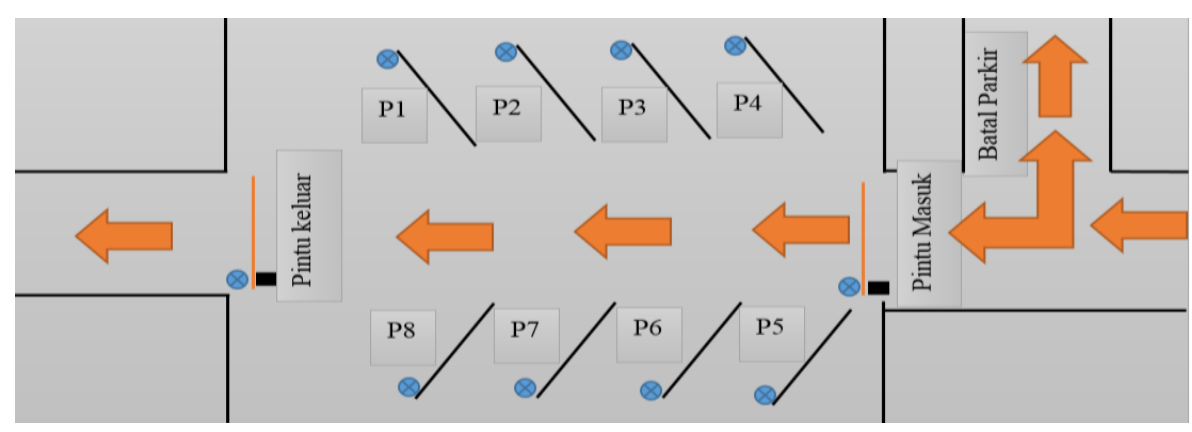

Gambar 8. Desain denah prototype area parkir

Keterangan pada gambar 8:
1. : Sensor Inframerah
2. $\square \quad$ : Motor Servo
3. $\quad$ P1 Kolom/slot parkir 1
4. P2 : Kolom/slot parkir 2
5. P3 : Kolom/slot parkir 3
6. P4 : Kolom/slot parkir 4
7. P5 : Kolom/slot parkir 5
8. P6 : Kolom/slot parkir 6
9. $\quad$ P7 : Kolom/slot parkir 7
10. $\mathrm{P} 8$
: Kolom/slot parkir 8

Pada gambar 8 terdapat 8 slot parkir yaitu slot 1 sampai dengan slot 8 tempat parkir. Sehingga jumlah slot parkir keseluruhan yang akan ditampikan pada mobile apps android. Selain itu, di situ juga terdapat sensor inframerah dan juga motor servo.

\section{HASIL DAN PEMBAHASAN}

Penelitian yang di laksanakan sesuai dengan pengajuan proposal yang telah didiskusikan pada seminar proposal sebelumnya dengan beberapa penambahan. Pada penambahan yaitu adanya beberapa fitur baru yang telah dimasukan dalam metode pnelitian sebelumnya. Berikut ini adalah ulasan dari pembahasan hasil penelitian.

\subsection{Prototype Area Parkir}

Penelitian disini adalah implementasi sistem Internet of Thing (IoT) yang menghasilkan produk prototype. Adapun prototype yang dihasilkan adalah lahan parkiran berisi 8 slot tempat parkir yang di visualkan pada aplikasi android. Peranan aplikasi android sebagai media untuk order ketersediaan tempat parkir.

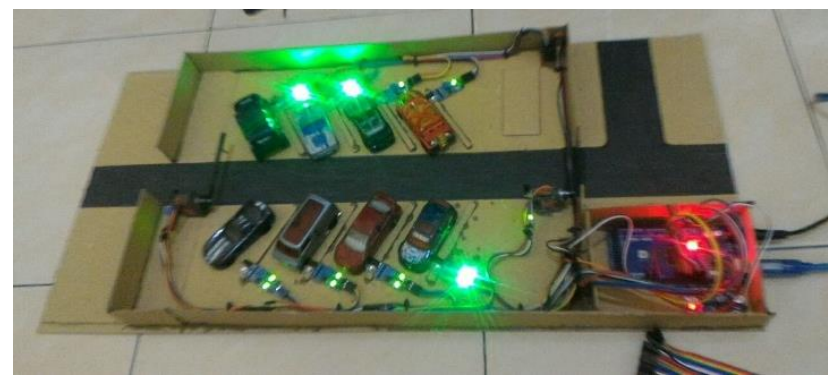

Gambar 9. Tampilan tempat parkir tampak belakang 


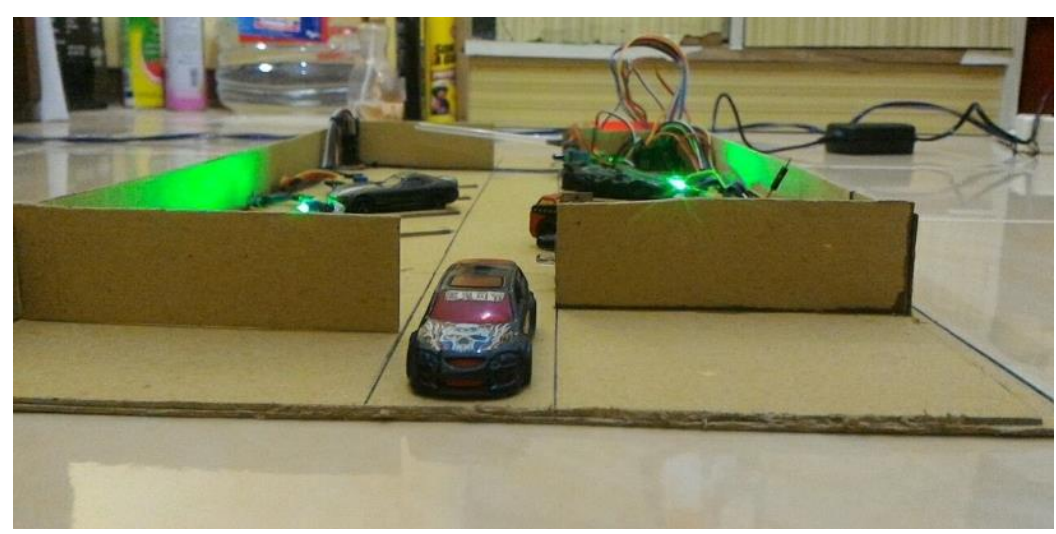

Gambar 10. Tampilan tempat parkir tampak atas

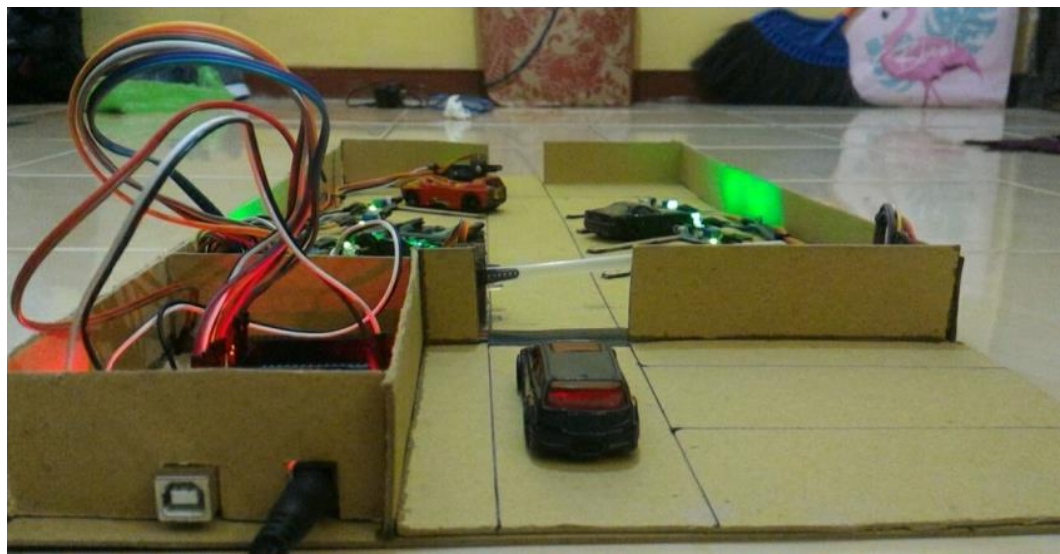

Gambar 11. Tampilan tempat parkir tampak depan

Sesuai dengan gambar 10 dimana terdapat delapan slot tempat parkir yang masing-masing slot tempat parkir memiliki perangkat keras sensor infra red untuk membaca kondisi slot parkir terisi atau kosong yang nantinaya dikirimkan ke server online. Selain pada slot tempat parkir pintu masuk dan juga pintu keluar dari prototype juga dipasangkan perangkat keras yaitu sensor infra red yang memiliki peranan fungsi untuk menutup pintu setelah di lewati oleh mobil yang akan masuk area parkir maupun keluar area parkir.

\subsection{Aplikasi Android}

\subsubsection{Cara Penggunaan Aplikasi pada Android}

1) Apabila sudah mempunyai akun yang terdaftar maka tinggal memasukkan akun tersebut pada aplikasinya.

2) Jika belum mempunyai akun maka bisa mendaftarkan dengan cara daftar akun seperti gambar berikut: 


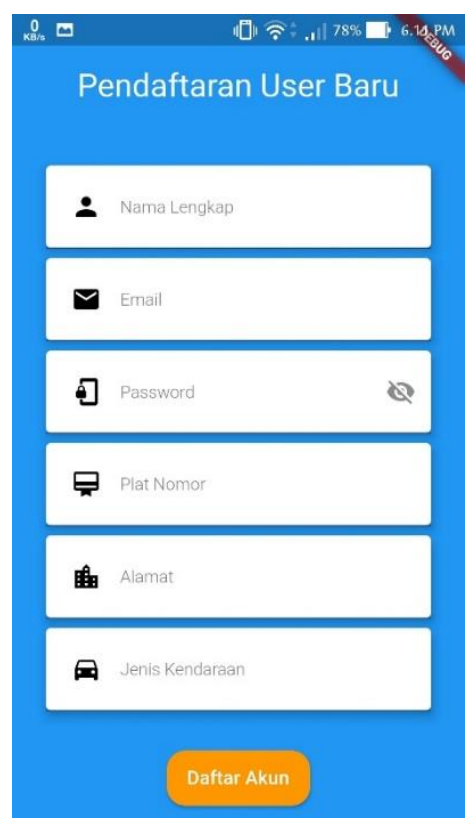

Gambar 12. Pendaftaran akun

3) Kemudian lengkapilah data sesuai dengan data pribadi anda.

4) Jika sudah tinggal masukkan akun yang telah dibuat tadi.

\subsubsection{Antar Muka (Interface) dan Fungsional}

Memiliki 4 menu bottom utama yaitu home atau bisa disebut juga beranda, menu riwayat parkir, menu parkir dan menu akun.

1) Menu Home

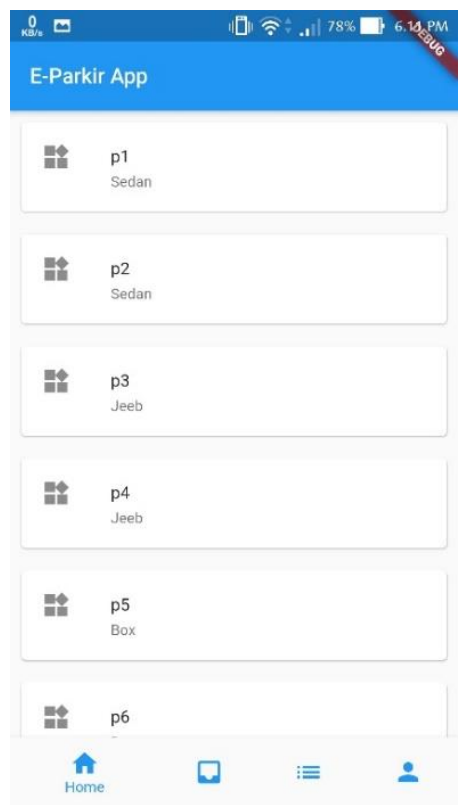

Gambar 13. Data ketersediaan tempat parkir

Gambar 13 adalah gambar dari daftar slot tempat parkir dimana ada ditabel pada salah satu tempat parkir seperti contoh dalam laporan ini disekenariokan untuk memilih pada slot tempat parkir P1. Berarti nantinya yang dipilih untuk tempat parkir adalah pada slot tempat parkir P1 untuk di order sementara akan lanjut menampilkan antar muka seperti berikut: 


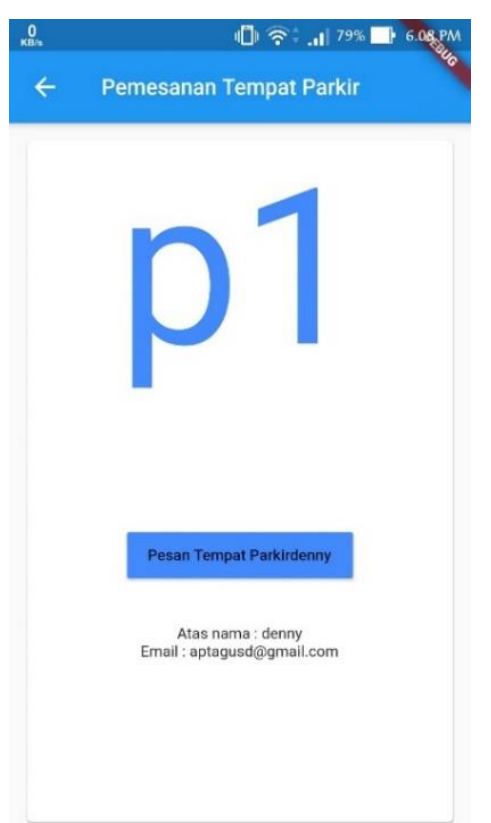

Gambar 14. Pemesanan tempat parkir

Antarmuka yang di tampilkan setelah melakukan tap pada slot tempat parkir P1 terdapat tombol yang dengan keterangan nama pemesan untuk melanjutkan pemesanan tersebut. Kelanjutan dari pemesanan akan menampilkan antar muka seperti berikut ini.

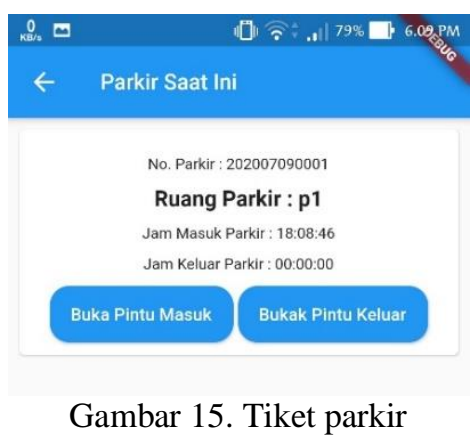

Tiket parkir disini bersifat terbatas waktu apa bila dalam kurun waktu lebih dari 30 menit tidak ada aktifitas dari tiket tersebut maka akan reset secara otomatis atau pemesanan sementar di hapuskan oleh sistem yang berlaku. Pada tiket juga tertera tombol buka pintu masuk dan buka pintu keluar, yang mempunyai fungsi untuk membukan palang pintu masuk dan keluar. Dalam segi keamanan tanpa tiket elektrik tersebut maka pintu-pintu tersebut tidak akan bisa terbuka kecuali pihak petugas yang membukakan. Terdapat juga jam masuk dan jam keluar parkir untuk menujukan jarak waktu dari awal masuk tempat parkir sampai dengan keluar tempat parkir. 
2) Menu Riwayat

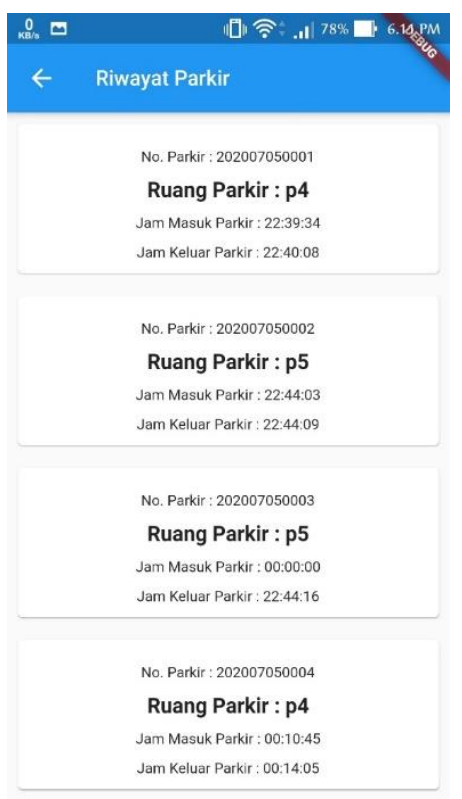

Gambar 16. Riwayat tempat parkir

Pada menu riwayat ini akan berisikan antar muka daftar kegiatan parkir yang sudah selesai atau yang sudah dilaksanakan. Sehingga bila belum ada kegiatan parkir yang belum selesai maka tudak akan ada daftar data yang di tampilkan.

3) Menu Parkir

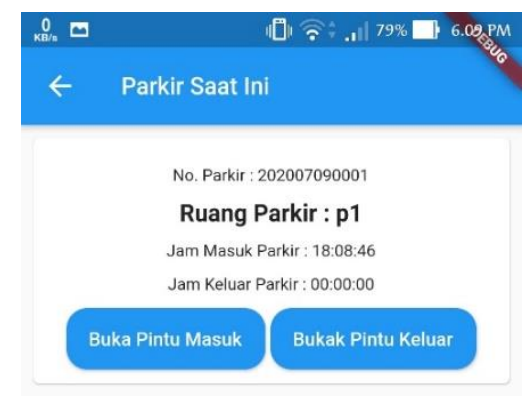

Gambar 17. Tiket hasil akhir

Pada menu parkir ini berisikan tentang ruang parkir yang telah dipesan kemudian waktu pertama kali parkir sampai dengan waktu keluar parkir dan ada tombol akses untuk membuka dan menutup palang pintunya. 
4) Menu Akun

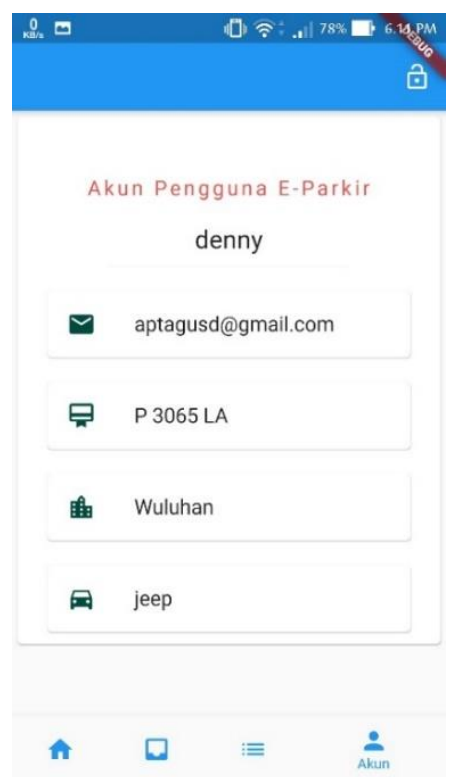

Gambar 18. Informasi akun aplikasi

Pada menu akun berisikan tentang data pribadi pengguna yang sesuai dengan aslinya.

5) Menu Pendaftaran User Baru

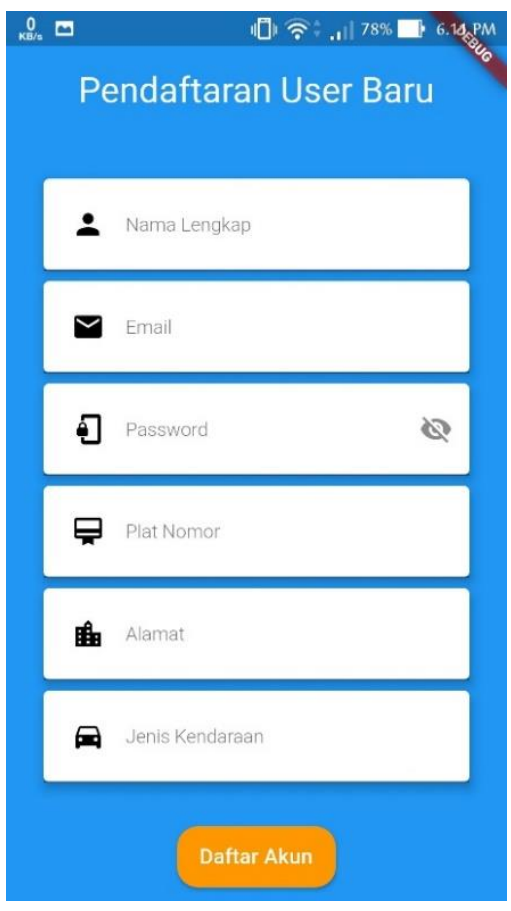

Gambar 19. Pendaftaran user baru

Pada menu ini berisikan tentang pendaftaran user baru apabila pengguna belum mempunyai akun tersebut. 


\subsubsection{Tampilan pada Web}

\section{EParkir}

\section{Simulasi Lahan Parkir}

\begin{tabular}{|l|l|l|l|}
\hline No & LOKASI PARKIR & STATUS & AKSI \\
\hline 1 & $\mathrm{p} 1$ & 1 & Edit Delete \\
\hline 2 & $\mathrm{p} 2$ & 1 & Edit Dolete \\
\hline 3 & $\mathrm{p} 3$ & 1 & Edit Dolote \\
\hline 4 & $\mathrm{p} 4$ & 1 & Edit Dolete \\
\hline 5 & $\mathrm{p} 5$ & 1 & Edit Delete \\
\hline 6 & $\mathrm{p} 6$ & 1 & Edit Dolete \\
\hline 7 & $\mathrm{p} 7$ & 1 & Edit Delete \\
\hline 8 & $\mathrm{p} 8$ & 1 & Edit Delete \\
\hline
\end{tabular}

Gambar 20. Tampilan pada server web ketika keaadaan kosong

$$
\text { EParkir }
$$

\section{Simulasi Lahan Parkir}

\begin{tabular}{|c|c|c|c|}
\hline No & LOKASI PARKIR & STATUS & AKSI \\
\hline 1 & p1 & 1 & Edit Dolete \\
\hline 2 & p2 & 0 & Edit Delete \\
\hline 3 & p3 & 1 & Edit Delete \\
\hline 4 & $\mathrm{p} 4$ & 0 & Edit Delote \\
\hline 5 & p5 & 1 & Edit Dolote \\
\hline 6 & p6 & 0 & Edit Delete \\
\hline 7 & p7 & 1 & Edit Delete \\
\hline 8 & p8 & 1 & Edit Dolete \\
\hline
\end{tabular}

Gambar 21. Tampilan pada server web ketika keadaan ada yang terisi dan tidak

Keterangan pada gambar diatas:

a) Lokasi parkir yaitu dimana tempat untuk menaruh mobil yang sudah sesuai dengan yang telah dipesan.

b) Status yaitu ketika kondisi 1 maka slot parkir masih kosong dan apabila kondisi 0 maka slot parkir sudah terisi atau sudah dipesan oleh pengguna apps.

c) Aksi dimana untuk mengedit atau menghapus tempat lokasi parkir sesuai dengan yang diinginkan server.

Pada gambar 4.13 adalah gambar slot parkir yang berada pada server web dan akan ditampilkan dimonitor.

\subsection{Pengujian Integrasi Antara Mobile Apps Android Dengan Prototype Tempat Parkir}

Setelah melaksanakan sebuah penelitian tentu kita perlu mengujinya baik dari sisi teknis maupun dari sisi fungsional hasil adapun pengujian meliputi kesesuaian fungsi dan juga ketidaksesuain fungsi. Dimana hasil dari pengujian akan digunakan sebagai pengukuran keberhasilan atas implementasi dari teori-teori yang diiplementasikan. Selain mencatat nilai keberhasilan atau kesesuaian dari penelitian juga dibutuhkan catatan berapa nilai kegagalan implementasi yang dapat digunakan sebagai kesimpulan dari penelitian, yang berguna untuk pengembangan pada penelitian terkait berikutnya. 
Tabel 1. Pengujian fungsi

\begin{tabular}{|c|c|c|c|c|}
\hline No & Nama Fitur & Kondisi Status & $\begin{array}{l}\text { Keterangan } \\
\text { Keberhasilan }\end{array}$ & $\begin{array}{l}\text { Keterangan } \\
\text { Kegagalan }\end{array}$ \\
\hline 1 & $\begin{array}{l}\text { Menghasilkan ketersediaan slot } \\
\text { parkir dari sisi smarthphone }\end{array}$ & 1 & Berhasil & - \\
\hline 2 & $\begin{array}{l}\text { Memesan slot tempat parkir } \\
\text { yang diinginkan dari sisi } \\
\text { smartphone }\end{array}$ & 1 & Berhasil & - \\
\hline 3 & $\begin{array}{l}\text { Menerima jam informasi } \\
\text { dimulainya awal parkir dimulai } \\
\text { dari smart phone }\end{array}$ & 1 & Berhasil & - \\
\hline 4 & $\begin{array}{l}\text { Membuka palang pintu masuk } \\
\text { area parkir dari sisi smartphone }\end{array}$ & 1 & Berhasil & - \\
\hline 5 & $\begin{array}{l}\text { Informasi kondisi tempat parkir } \\
\text { setelah dipesan pada kondisi } \\
\text { tersedia atau sudah terisi }\end{array}$ & 1 & Berhasil & - \\
\hline 6 & $\begin{array}{l}\text { Membuka palang pintu keluar } \\
\text { area parkir dari sisi smartphone }\end{array}$ & 1 & Berhasil & - \\
\hline 7 & $\begin{array}{l}\text { Informasi jam berakhir setelah } \\
\text { membuka pintu keluar dari sisi } \\
\text { smartphone }\end{array}$ & 1 & Berhasil & - \\
\hline 8 & $\begin{array}{l}\text { Menerima data untuk membuka } \\
\text { pintu masuk dari sisi prototype }\end{array}$ & 1 & Berhasil & - \\
\hline 9 & $\begin{array}{l}\text { Mengirimkan informasi } \\
\text { penempatan mobil sesuai } \\
\text { tempat parkir yang di pesan dari } \\
\text { sisi prototype }\end{array}$ & 1 & Berhasil & - \\
\hline 10 & $\begin{array}{l}\text { Menerima data untuk membuka } \\
\text { pintu keluar dari sisi prototype }\end{array}$ & 1 & Berhasil & \\
\hline
\end{tabular}

Tabel 1 adalah data pengujian fungsional yang telah dilaksanakan dalam penelitian dimana pengujian telah di sesuaikan dengan pola dan desain dari pengajuan penelitian. Ditabel juga ada kondisi status jika 1 maka kondisi berhasil dan jika kondisi status 0 maka kondisi tersebut tidak berhasil. Adapun data pengujian tersebut berasal dari loger yang tercatat secara manual. Catatan loger manual tersebut dibuat sebagai catatan yang sebenar-benarnya dalam pengerjaan penelitian. Berikut beberapa tabel dari catatan loger manual:

Percobaan 1

Tabel 2. Tabel data loger percobaan pengujian 1

\begin{tabular}{llll}
\hline Kolom Parkir & $\begin{array}{l}\text { Waktu Respon Palang } \\
\text { Pintu Masuk }\end{array}$ & $\begin{array}{l}\text { Waktu Respon Palang } \\
\text { Pintu Keluar }\end{array}$ & $\begin{array}{l}\text { Waktu Respon Kolom } \\
\text { Parkir }\end{array}$ \\
\hline p1 & 1.59 menit & 2.48 menit & 1.79 menit \\
p2 & 1.57 menit & 2.47 menit & 2.39 menit \\
p3 & 1.60 menit & 2.49 menit & 2.52 menit \\
p4 & 1.55 menit & 2.48 menit & 2.07 menit \\
p5 & 1.58 menit & 2.46 menit & 2.46 menit \\
p6 & 1.57 menit & 2.47 menit & 1.53 menit \\
p7 & 1.56 menit & 2.48 menit & 2.43 menit \\
p8 & 1.57 menit & 2.60 menit & 2.52 menit \\
Rata Rata & 1.57 menit & 2.48 menit & 2.52 menit \\
\hline
\end{tabular}

Percobaan 2 
Tabel 3. Tabel data loger percobaan pengujian 2

\begin{tabular}{llll}
\hline Kolom Parkir & $\begin{array}{l}\text { Waktu Respon Palang } \\
\text { Pintu Masuk }\end{array}$ & $\begin{array}{l}\text { Waktu Respon Palang } \\
\text { Pintu Keluar }\end{array}$ & $\begin{array}{l}\text { Waktu Respon Kolom } \\
\text { Parkir }\end{array}$ \\
\hline p1 & 1.60 menit & 2.47 menit & 1.81 menit \\
p2 & 1.58 menit & 2.48 menit & 2.41 menit \\
p3 & 1.59 menit & 2.49 menit & 2.51 menit \\
p4 & 1.60 menit & 2.48 menit & 2.05 menit \\
p5 & 1.57 menit & 2.50 menit & 2.48 menit \\
p6 & 1.56 menit & 2.47 menit & 1.52 menit \\
p7 & 1.60 menit & 2.48 menit & 2.44 menit \\
p8 & 1.57 menit & 2.48 menit & 2.51 menit \\
Rata Rata & 1.60 menit & 2.48 menit & 2.51 menit \\
\hline
\end{tabular}

Percobaan 3

Tabel 4. Tabel data loger percobaan pengujian 3

\begin{tabular}{llll}
\hline Kolom Parkir & $\begin{array}{l}\text { Waktu Respon Palang } \\
\text { Pintu Masuk }\end{array}$ & $\begin{array}{l}\text { Waktu Respon Palang } \\
\text { Pintu Keluar }\end{array}$ & $\begin{array}{l}\text { Waktu Respon Kolom } \\
\text { Parkir }\end{array}$ \\
\hline p1 & 1.60 menit & 2.47 menit & 1.77 menit \\
p2 & 1.58 menit & 2.49 menit & 2.37 menit \\
p3 & 1.57 menit & 2.48 menit & 2.52 menit \\
p4 & 1.59 menit & 2.49 menit & 2.06 menit \\
p5 & 1.57 menit & 2.46 menit & 2.44 menit \\
p6 & 1.59 menit & 2.50 menit & 1.52 menit \\
p7 & 1.58 menit & 2.47 menit & 2.41 menit \\
p8 & 1.59 menit & 2.48 menit & 2.52 menit \\
Rata Rata & 1.59 menit & 2.48 menit & 2.52 menit \\
\hline
\end{tabular}

Percobaan 4

Tabel 5. Tabel data loger percobaan pengujian 4

\begin{tabular}{llll}
\hline Kolom Parkir & $\begin{array}{l}\text { Waktu Respon Palang } \\
\text { Pintu Masuk }\end{array}$ & $\begin{array}{l}\text { Waktu Respon Palang } \\
\text { Pintu Keluar }\end{array}$ & $\begin{array}{l}\text { Waktu Respon Kolom } \\
\text { Parkir }\end{array}$ \\
\hline p1 & 1.57 menit & 2.48 menit & 1.80 menit \\
p2 & 1.60 menit & 2.49 menit & 2.41 menit \\
p3 & 1.58 menit & 2.48 menit & 2.53 menit \\
p4 & 1.57 menit & 2.47 menit & 2.05 menit \\
p5 & 1.58 menit & 2.48 menit & 2.43 menit \\
p6 & 1.57 menit & 2.49 menit & 1.52 menit \\
p7 & 1.59 menit & 2.47 menit & 2.42 menit \\
p8 & 1.60 menit & 2.49 menit & 2.52 menit \\
Rata Rata & 1.57 menit & 2.48 menit & 2.52 menit \\
\hline
\end{tabular}

- Jumlah Rata Rata Keseluruhan Waktu Proses Palang Pintu Masuk:

Percobaan 1+ Percobaan $2+$ Percobaan $3+$ Percobaan $4=$

$1.57+1.60+1.59+1.57=6.33$ menit

Waktu rata rata akses pintu masuk membutuhkan waktu 6.33/4=1.58 menit

- Jumlah Rata Rata Keseluruhan Wakt Proses Palang Pintu Keluar:

Percobaan $1+$ Percobaan $2+$ Percobaan $3+$ Percobaan $4=$

$2.48+2.48+2.48+2.48=9.92$ menit

Waktu rata rata akses pintu keluar memerlukan waktu 9.92/4 $=2.48$ menit

- Jumlah Rata Rata Keseluruhan Waktu Respon Kolom Parkir:

Percobaan 1+ Percobaan $2+$ Percobaan $3+$ Percobaan $4=$

$2.52+2.51+2.52+2.52=10.07$ menit

Rata rata waktu respon pengguna kolom parkir memerlukan waktu 10.07/4 = 2.52 menit

- Hitung keberhasilan kehandalan waktu respon palang pintu masuk (a) dan respon palang pintu keluar (b):

Percobaan 1: Pintu masuk (a) $R=\frac{1.57}{1.60} \times 100 \%=98.13 \%$

Pintu keluar (b) $R=\frac{2.48}{2.50} \times 100 \%=99.2 \%$ 


$$
\begin{gathered}
R s=\frac{a+b}{2}=\frac{98.13+99.2}{2}=147.73 \% \\
\text { Percobaan 2: Pintu masuk: (a) } R=\frac{1.60}{1.60} \times 100 \%=100 \% \\
\text { Pintu keluar :(b) } R=\frac{2.48}{2.50} \times 100 \%=99.2 \% \\
R s=\frac{a+b}{2}=\frac{100+99.2}{2}=149.6 \% \\
\text { Pecobaan 3: Pintu masuk (a): } R=\frac{1.59}{1.60} \times 100 \%=99.38 \% \\
\text { Pintu keluar (b): } R=\frac{2.48}{2.50} \times 100 \%=99.2 \% \\
R s=\frac{a+b}{2}=\frac{99.38+99.2}{2}=148.98 \% \\
\text { Percobaan 4: Pintu masuk (a): } R=\frac{1.57}{1.60} \times 100 \%=98.13 \% \\
\text { Pintu masuk (b): } R=\frac{2.48}{2.50} \times 100 \%=99.2 \% \\
R s=\frac{a+b}{2}=\frac{98.13+99.2}{2}=147.73 \%
\end{gathered}
$$

Dari tabel 2 sampai dengan tabel 5 adalah empat kali percobaan pengujian untuk mengetahui nilai kecepatan waktu respon aplikasi terhadap prototype . Dimana pengujian tersebut dilakukan pada waktu-waktu tertentu yang dirasa menjadi waktu jam masuk kantor dan juga waktu jam pulang kantor.

\section{KESIMPULAN}

Point-point dari penelitian telah dilaksanakan sesuai dengan pola dan desain penelitian yang diusulkan yang kemudian ditindak lanjutkan dengan pelaksanaan penelitian. Dari beberapa tahapan dan langkahlangkah penelitian maka akan disimpulkan sebagai berikut:

1) Dengan implementasi Internet of Thing (IoT) dapat dihasilkan produk prototype, dan pada prototype tersebut dihasilkan lahan parkir yang berisi 8 slot yang divisualkan pada aplikasi android.

2) Antarmuka mobile apps android di buat untuk mendukung kinerja dari prototype area parkir tersebut dan didalam aplikasi terdapat beberapa fungsi-fungsi tertentu yaitu seperti menu home, menu riwayat, menu parkir, menu akun dan menu untuk login.

3) Dengan cara pengujian integrasi antara mobile apps android dengan prototype tempat parkir di dapatkan waktu rata rata akses pintu masuk membutuhkan waktu 1.58 menit dan waktu rata rata akses pintu keluar memerlukan waktu 2.48 menit.

4) Rata rata waktu respon pengguna kolom parkir memerlukan waktu 2.52 menit.

\section{REFERENSI}

[1] Wikipedia. 2019. "Parkir". [Online]. Tersedia di : https://id.m.wikipedia.org/wiki/Parkir [Diakses: 10 Oktober 2019].

[2] Famosa Studio Blog. 2013. “Arduino Mega 2560". [Online]. Tersedia di : https://blog.famosastudio.com/2013/09/produk/arduino-mega-2560/531 [Diakses: 10 Oktober 2019].

[3] Arifzakariya. 2012. "Komunikasi Serial Mikrokontroler". [Online]. Tersedia di: https://arifzakariya.blog.ugm.ac.id/2012/01/09/komunikasi-serial-mikrokontroler/ [Diakses: 10 Oktober 2019].

[4] Wordpress. 2014. "Pengetahuan Dasar dan Pemrograman Raspberry Pi". [Online]. Tersedia di: https://pccontrol.wordpress.com/2014/06/17/pengetahuan-dasar-dan-pemrograman-respberry-pi/ [Diakses: 10 Oktober 2019].

[5] Rayenvp97. 2015. "Sensor Inframerah". [Online]. Tersedia di: https://rayendente.wordpress.com/2015/03/26/sensor-inframerah/ [Diakses: 10 Oktober 2019].

[6] Rasjid, F. E. 2018. “Android: Sistem Operasi Pada Smartphone". [Online]. Tersedia di: https://www.ubaya.ac.id/2018/content/articles_detail/7/Android--Sistem-Operasi-padaSmartphone.html [Diakses: 10 Oktober 2019].

[7] Wikipedia. 2018. "Penampil Kristal Cair". [Online]. Tersedia di: https://id.m.wikipedia.org/wiki/Penampil_krital_cair [Diakses: 10 Oktober 2019]. 
[8] Dewaweb. 2018. "Internet of Things". [Online]. Tersedia di: https://www.dewaweb.com/blog/internetof-things/ [Diakses: 10 Oktober 2019].

\section{BIOGRAFI PENULIS}

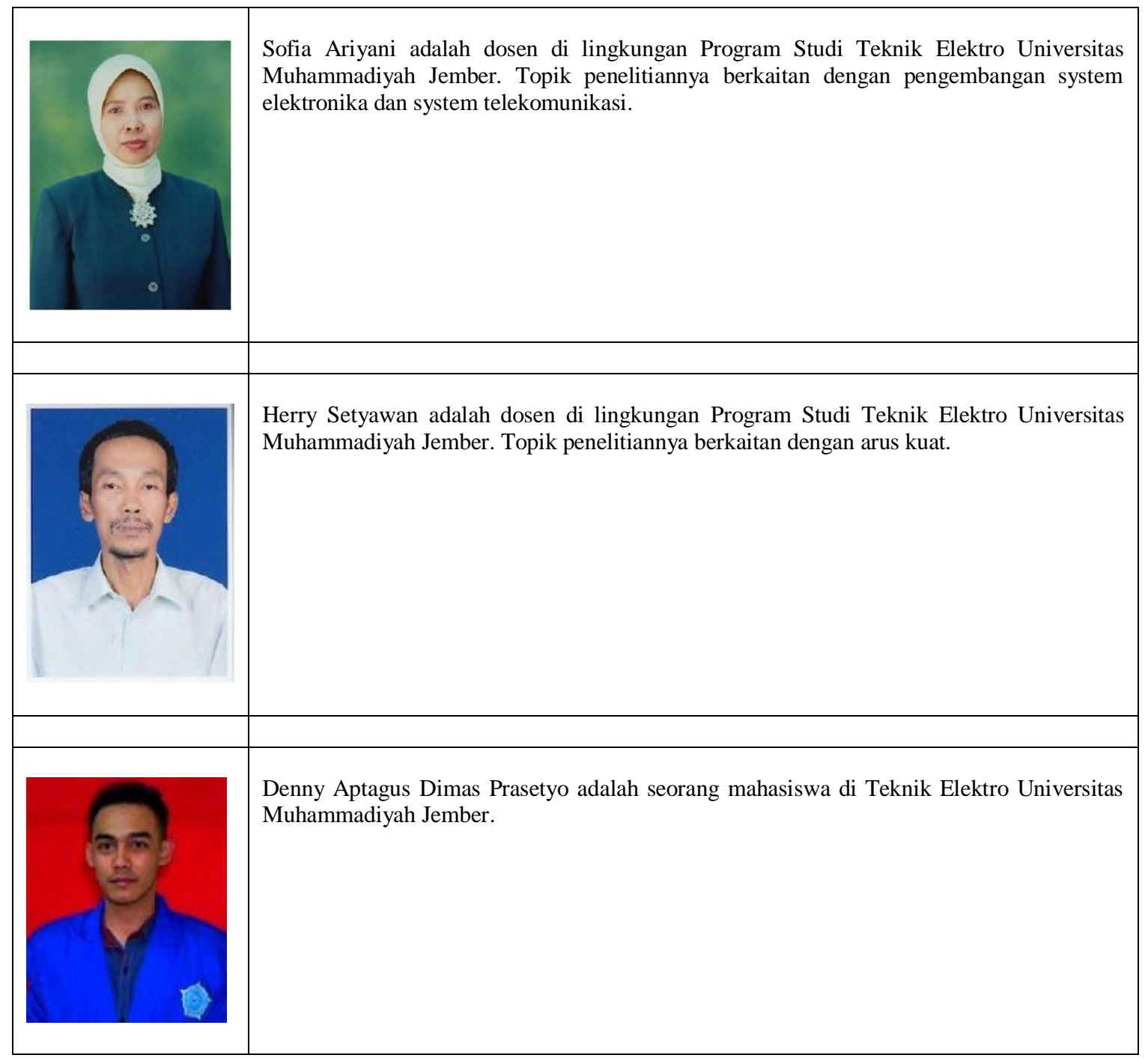

